\title{
Community Awarenes and Child-Friendly School at the District Nonghet, Northern of Lao PDR
}

\author{
Agustinus Hermino $^{1}$ \& Viengdavong Luangsithideth ${ }^{2}$ \\ ${ }^{1}$ Kanjuruhan University, Malang, Indonesia \\ ${ }^{2}$ Ministry of Education and Sports, Lao PDR \\ Correspondence: Agustinus Hermino. E-mail: agustinus@unikama.ac.id
}

Received: August 30, 2017

doi:10.5539/ass.v13n11p109
Accepted: September 9, $2017 \quad$ Online Published: October 28, 2017

URL: https://doi.org/10.5539/ass.v13n11p109

\begin{abstract}
This qualitative research has purpose in order to get deep meaning of community awareness and child-friendly school at the District Nonghet, Northern of Lao PDR, relate with aspect of: (1) strengthening of Lao language as an instructional language in the school; (2) child participation to come to school; (3) role of Village Education Development Committee (VEDC); (4) child-friendly school with local wisdom. Location of the research were in four village groups at the Nonghet district, Xieng Khouang Province. The result of this research indicates that quality education and be improved if there is real involvement by the community, and community awareness and child-friendly school can be addressed, based on: (1) strong education in the family; (2) the importance of attention to the socially outside of school; (3) atmosphere environment in school; (4) methods of theaching by teacher; (5) strengthen the role of teaches as learner and educator; (6) strengthen relationship teacher-student-parent; (7) exempary habituation; (8) implementation of curriculum-based character in the teaching learning process; (9) strengthen of character education; (10) strengthen the role of school principal.
\end{abstract}

Keywords: community awareness, child-friendly school, community pasticipation

\section{Introduction}

District Nonghet is a part of Xieng Khouang Province, which is located in the Northern Lao PDR. This district is direct border with Viet Nam. Community in the District Nonghet is Hmoung etnich who lives on farms and plantations. In the tradition of Hmoung etnich, children are an asset to the family, because children can be assigned to the tasks of helping parents, before and after school. There is also a previous assumption that children do not need school because in the future they will also work in the garden for their life and their future.

Nevertheless, since 2010 with the education project of ChildFund Laos which is part of ChildFund Australia, the notion of the importance of education by the majority of the community has begun to diminish, since the community participation approach by ChidFund Laos has made people more aware of the importance of education for their children.

Previous research by Pearce (2011) found that due to low public awareness of the importance of education, schooling for children is considered to be a less profitable activity especially for girls because they have to work to help their parents or husbands if they have dropped out of school and married in young age.

Munro \& Howe (2013) suggests that since the education ministry has limited human resources to reach all villages in Laos, the government seeks to optimize community participation in education development, in three synergies: local government, education departments in the regions, and village councils.

Similarly, research conducted by Seel, et al (2015) suggests that in order to increase public participation in educational development, it is necessary to have Village Education Development Committees that serve as the extraneousness of the government to the community. This VEDC's have a similar level of responsibilities that include, but are not limited to: collecting data on total number of families (including poor families) and facilitate their inclusion and completion of basic education; and summarize, research and analyze problems in education (including students, teachers, buildings, materials).

Improving communities' perceptions of the value of education overall, and for children in particular, is key to improving children participation rates in school. Parents are the key decision makers and influence greatly the 
level of opportunity children can have to focus on their education. In the communities studied many of the parents have not received much formal education and do not speak the Lao language used in schools. Despite this there are parents, particularly mothers, who want a better life for their children to study longer. Advocacy campaigns to raise awareness of the benefits of education and to change community perceptions about the value of children education have been used effectively in many countries of the world.

Strengthening education quality with the basis of school and community can be addressed with an education campaigns delivered to parents via community leadership promoting the benefits to the community, families and children of education could capitalise on these feelings among parents. Opportunities for convincing communities of the value of pre-primary and primary education for their children include: a) stronger village leadership and greater ability to liaise with district authorities because more people in the village could communicate in Lao language; b) the possibility of more trained teachers and health care workers in villages; c) development of economic opportunities for villages. With a good economic improvement will support the awareness of the community about the educational experience of children in the framework towards a better life for their children and future generations.

In the School-Based Management (SBM) is known 3 pillars, namely: a) school management with the main role is the school principal who plays both as a leader and manager in the school community; b) joyful learning with the main role is the teacher, where teachers are required to be able to prepare learning materials to their students and convey with a pleasant atmosphere to their students during the teaching and learning process; and c) community participation, where the role is school committee. The role is not a complementary role in a school organisation but the school committee is also encouraged to contribute to school needs planning based on existing capabilities

\section{Method}

The research was conducted in four village groups at the Nonghet district, Xieng Khouang Province. Those villages are: (a) Nonghet Tai village group, consist of villages: 1) Paka, 2) Houaykheeleng, 3) Nonghet Tai, 4) Houaydeau, 5) Dindam, and 6) Kenglet; (b) Phakhai Tai village group, consist of villages: 1) Phakhai Tai, 2) Phakhae Neua, 3) Phamao, 4) Khorthong, 5) Houayzouang, 6) Nammen, 7) Namkongua, 8) Nongkop, and 9) Yorthkhor; (c) Pha-En village group, consist of villages: 1) Pha-En, 2) Khorkmu, 3) Phounong, 4) Bouamdao, 5) Pha-Ngon, and 6) Pha-Or; (d) Thamxay municipatity group, consist of villages: 1) Phaclac, 2) Nongxang, 3) Namkouang, 4) Nongkhieu, 5) Thamxay, and 6) Nonghet Neua.

The methodological framework employed for this project evaluation will be mainly qualitative and comprise of a mix of primary and secondary data collection techniques. Secondary data obtained from the documents such as: 1) school profiles, 2) strategic planning by education department at the province and district, 3) relevant project report. This qualitative research has some purpose in order to dig understanding about quality of primary education for children in Nonghet by strengthening school leadership, local teaching skills, and community awareness. Qualitative methods are effective to explore and understand phenomena by seeking different views from relevant research target groups (Johnson \& Christensen, 2008). The methods create direct and spontaneous ways of sharing information, expertise and experience between researchers and participants (Mikkelsen, 2005). Qualitative research, ideally, allows participants to freely express their opinions, thoughts and experiences in a deep and detailed manner (Creswell, 2009; Creswell, 2013). Therefore, qualitative research normally involves researchers meeting face to face with participants to conduct interactive interviews in a casual setting. Through qualitative interviews, researchers gradually create the meaning of a certain phenomenon. Researchers can also interpret the meaning of such phenomenon by drawing on personal reflection and existing literature (Creswell, 2013; Johnson \& Christensen, 2008). Using a combined approach of document review, semi-structured interviews and participant observation, enables researchers to generalise, explain and draw conclusions on issues that vary from their expectations (Fitzgerald, 2006).

Primary data is done by researchers with direct interviews to all informants who know well about the project and also direct involve to the project, such as: teachers, parents, students, community leaders, woman union, team from District Education and Sports Bureau (DESB) at the Nonghet District, and also team from Provincial Education and Sport Services (PESS) at the Xieng Khouang Province. Researchers are assisted by a local translator as a volunteer who can speak Moung, Laos, and English, in addition researchers are also assisted by 4 staffs from the ChildFund Laos (CFL) in the accumulation of informants and facilitate in extracting information.

Some limitation of this research such as: (1) the unavailability and lack of latest data on number of students and teachers hinder researchers to get detail and comprehensive picture of school condition; (2) distance between all targeted schools is lengthy and time consuming; (3) researcher have to consider the climate condition; (4) time 
limitation forced the research team to finish field survey before noon; and (5) most principals, teachers and parents were not present during the field survey due to school holiday and farming seasons.

Instrument in this research is the researchers themselves as a key instrument. Advantage researcher as key instrument is because it is responsive and adaptable. Researcher as the instrument be able to holistic emphasis, developing a knowledge-based expansion, the freshness of the immediacy process, and have the opportunity for clarification and summarize, and can take advantage of opportunity to investigate the response that special/odd or peculiar (explore atypical or idiosyncratic responses).

All informations obtained by researchers has received approval from education departments in provinces, districts and CFLs to determine the success and impact of the project.

\section{Findings}

First, the impact to the students. This condition can be seen from the participation rate of children to go to school become increase, and children feel comfortable in participating in learning in school because their attention from teachers through the application of the joyful learning. But the problem also arises that children get less attention in the family especially the support of parents to give attention to study the children at home. This is because most parents have been tired when they arrive at home all day long.

Second, the impact on teachers is that teachers have measured programs in the form of lesson plans and are able to apply innovative learning that is easily understood by students, but the problem still arrise that still lack of supervision form the school principal relate with the lesson plan which prepared by the teacher, or supervison from the pedagogic advisor (school supervisor) from the district or provincial level. General condition also arraise that still lots of teachers cannot make the lesson plan and also how to use the local materials for the learning materials.

Third, the impact on the community, that is, the community increasingly understand the importance of education for children in order to improve the better life, but the community also has not quite understood how to contribute in designing the annual school planning based on the needs of the school, as well as with participation in the maintenance of school buildings, especially during the school holiday. Nevertheless, the community is very enthusiastic to be able to contribute in giving influence to teachers for the progress of education in their village.

Fourth, the impact to the government, the best practice available on the ChildFund project can be adopted by the government in order to make relevant and measurable policies. However the problems that arise are about the use of laos as the language of instruction in learning, while in daily life the children use Moung language more so that children's understanding of the subject matter delivered in Laotian language is still not maximal. This is still a homework for the government at the provincial and district levels to place teachers who can understand Moung language as a local language and strategies in learning so that the material taught can be delivered well to the students.

\section{Results and Discussions}

\subsection{Strengthening of Lao Language as an Intructional Language in the Teaching Learning Process}

Daily language of the Hmoung etnich in the district Nonghet is the Moung language. There are three challenges faced by teachers in teaching in schools, such as: 1) the challenge from within the teachers themselves, that is most teachers who come from outside of the district Nonghet have lack understanding of Moung language so that the delivery of learning materials becomes not optimal; 2) the challenge of the students, that is, the students do not normally communicate using Lao language in their daily life especially at home, so that the learning materials received at school do not get the full support from their parents; and 3) the challenge of parent, that is, unusual parents communicate with Lao language to the child, this is due to the low comprehension of Laos language by parents, resulting in low parental support to the child while at home to provide motivation in learning.

First, challenge from within the teachers themselves, that is most teachers who come from outside of the district Nonghet have lack understanding of Moung language so that the delivery of learning materials becomes not optimal. Several attempts have been made by the government to distribute graduate students from universities majoring in teacher education from Nonghet District in particular or Xieng Khouang Province in general to be willing to be deployed as teachers in the area. Another effort is to provide debriefing about Moung culture and language to teachers who are not from the area to know the life of local people and speak in Moung language especially in giving introduction when learning process in the school. This condition is also as stated by Allen (1994) that one of the spirits of education for all is for children of their age to get a chance to get a proper 
education, so one of the efforts in higher education is for students who are learning about teacher education to get briefing on culture and language areas in the country as this will make it easier for the government to distribute teachers who are not from their own region. As well as Peng, et al (2013); Lane, et al (2014) suggests that in order to strengthen the education system in remote areas, it is necessary for the government to provide briefings to prospective teachers on regional, linguistic and cultural conditions in areas where teachers will be placed, when the teacher is placed in the new area then the teacher is ready. Referring to this condition, several things that need to be considered especially by the ministry of education are: (1) the need for school mapping containing at least among others the location of the school, the number of students, and the number of teachers; (2) accurate data on teacher teacher ratios; (3) the need for competency data base and teacher qualification; (4) the Ministry of Education and universities work together to register students who from the beginning of college are interested to become teachers so that by the time the student graduated, the central Government and Ministry of Education have prepared training and socialization program about local conditions, customs, culture and language areas for prospective teachers; and (5) the certainty of salary to be received by the prospective teachers.

Second, challenge of the students, that is, the students do not normally communicate using Lao language in their daily life especially at home, so that the learning materials received at school do not get the full support from their parents. The same thing also as proposed by Creamer \& Creamer (1994); Creamer (2000) that the use of that introduction in learning is the national language of the country, so it is necessary to learn about the national language in a country. Furthermore, research conducted by Pearce (2011); Munro \& Howe (2013); Wiles, et al (2008) argues that it is very important for teachers to use the national language as an intructional language in conveying the subjects they teach to the students, so that for teachers placed in areas where the use of local languages is still high than the use of national language, then still need an understanding of the local language of the area is required. In this regard, the "one Lao word per day" program is very relevant to introduce and familiarize children to recognize and use Laotian as the national language in daily life at school. Nevertheless, the use of national language in everyday life in the school will have an impact on students' understanding to get to know the lessons they learn when there is support and attention from parents when the child is at home. The importance of learning support from parents to students while at home is also as stated in UNESCO (2015) that the habits of parents to speak in the national language of the country, as well as the attention of parents to children while studying at home will make it easier for children to understand the lessons learned in school.

Third, challenge of parent, that is, unusual parents communicate with Lao language to the child, this is due to the low comprehension of Laos language by parents, resulting in low parental support to the child while at home to provide motivation in learning. It is very important that the need for adult education, especially in the community about the use of national language in daily conversation for children. This does not mean to eliminate the use of local languages but rather to provide habituation for adults and the public about the importance of getting to know the national language, so that people can know the development of their country in general, and specifically to provide learning support to their children while at home. It is also as suggested by Trumbull (2003); Skaalvik \& Skaalvik (2013), that the national curriculum in a country needs to pay attention to aspects of education in the family, which can contribute to the learning achievement of children. Referring to this condition, it is necessary for family education programs in remote areas where the use of the national language is still minimal, it is important to do, because the strengthening of education in the family will contribute to the progress of education in schools.

\subsection{Increasing of Child Participation to Come to School}

Some changes in knowledge, attitude or practice/behaviour experienced by the target groups that may be attributable to the projects, such as: (1) from the students aspect, students start to be happy to go to school because the teachers teach in a fun atmosphere, and students feel proud because their work is displayed in the classroom. Yet many students said that they want books to learn to be brought home, and mathematics is still a difficult lesson. In the other hand, students also have bravely to inform to the school principal if the teacher absent or give punishmnet. This condition is aspect monitoring and evaluation from the students to the teacher or school environment; (2) from school principal and teachers aspect, pedagogic training methods are helpful for them to improve the quality of teaching, but there is still a need for advance training efforts especially in multigrade teaching methods. Schools also need school libraries to support students diligently reading especially in Lao language; (3) from community aspect, the community began to grow awareness of the importance of education for children, but still needed assistance for education in the family because with the current technological developments, most parents pay more attention to using existing technology tools rather than pay attention to education in children; and (4) from education department aspect in the province and district level, best practice of the projects can be used as sustainable education development programs, but due to limited 
resources and funding, the cooperation between ChildFund and the education department at the provincial and district levels still needs to be improved.

Implementation of joyful learning in school will greatly help students to be able to think creatively and have the courage to explore themselves in the creative during the learning in school took place. Nevertheless, the key to the success of joyful learning remains in the readiness of teachers in preparing lesson plans before learning starts and is also supported by the supervisory function of the principal to the teacher. Steer \& Wathne (2010) argued that if due to limited resources owned by the government, then with the cooperation with Non Government Organizations (NGOs) that focus on education will be easier for teachers to get training on joyful learning following the theory and practice. Similar opinion was also raised by Slameto (2010), Hermino (2015); Hermino (2017) the key to the success of joyful learning is the synergy between teachers, principals, and school supervisors, because the synergy will focus on the ability of teachers to deliver the subject matter well in a comfortable and acceptable setting for students in the classroom. The same thing was also raised by Misco (2007); Fullan (2007) that the ability of the principal to delegate his authority to the teacher will give a sense of responsibility from the teacher to be able to do his job well.

With such a good working relationship and with the increasing pasrisipasi children to come and study in school, then indirectly has brought teachers to further improve their work motivation. The number of factors in the work that affect the motivation of individual work as follows: (1) sense of security (security), namely the certainty of teachers to obtain permanent employment, taking office in schools through a transparent, objective and measurable process; (2) the opportunity to progress (type of work), namely the possibility to advance, level up, gain position and expertise; (3) the type of work, that is, the work in accordance with the educational background, experience, talents, and interest of the teacher in developing the career; (4) the name of the place of employment (the company), ie the school or teacher organization which gives pride to its members when working in such school or teacher organization; (5) co-worker, a like-minded colleague, suitable for cooperation; (6) salary (salary), ie fixed and fixed income received in each month; (7) supervisor, ie a leader or superior who has good relations with his subordinates, knows his subordinates, and considers the opinions expressed by his subordinates; (8) working hours, ie regular or specific working hours of the day; (9) working place conditions, such as workplace hygiene, temperature, work space, ventilation, noise, odor, etc.; and (10) facilities (benefit), namely the opportunity to leave, health insurance, medication and so forth.

\subsection{The Role of Village Education Development Committee (VEDC) as a Part of Reinforcement of School-Based Management (SBM)}

VEDC is an extension of the government to the grassroots community. One of the main tasks of this VEDC is to provide understanding for parents to raise awareness and awareness of the importance of education for children, as well as to help schools in planning the school's annual program that is relevant for the advancement of education in schools and villages. UNESCO (2015) argues that community involvement in improving the quality of education in the village will have an impact on improving the quality of life in the village. With this VEDC, indirectly the government has invited the community to participate in the development of education in the region. However, there are some things that still become homework of the local government, such as: (1) strengthening VEDC governance of their roles and duties; (2) the authority relationship between the VEDC, the village government and the school; (3) the existence of a more strategic advisory program from the local government to VEDC as required by the facilitator who serves to provide assistance and organizational insight. This condition is also in line with that proposed by Viengdavong, et al (2017), which is required by government policy to target education quality improvement program in area through strategic effort with existence of community empowerment program in education field.

Furthermore, Myers \& Stonehill (1993); Munro \& Howe (2013) argued that SBM is a strategy to improve education by transferring decision making authority from central and regional administration to the schools internally. SBM gives principals, teachers, parents and public more control in education and responsibility to make decision on budget, personnel and curriculum.

With the involvement of local stakeholders in making decision it is expected that SBM can improve the quality of effective learning environment for students. Three main pillars of SBM are: (1) Accountable school management, (2) Implementation of AJEL method and (3) Social participation (UNICEF, 2010). Based on this condirion, then can be interpreted that characteristics of schools that implemented SBM are: (1) school organisation has the characteristics: (a) provides transformational management/leadership to achieve school's purpose, (b) formulates school plans and policies for its own, (c) guarantees an active communication between school and public, (d) empowering social participation; (2) Teaching and learning activities, have the 
characteristics: (a) develops suitable curriculum to responds public and student's needs, (b) implements effective learning activities and development program for students; and (3) human resources, have the characteristics: (a) empowering personnel and staff with SBM insight to serve students, (b) provides programs to develop staff's skills, (c) implements forum to discuss school's progress and performance.

\subsection{Child-Friendly School with Local Wisdom}

Child-friendly school is intended to put more children's rights to receive education in the aspect of a pleasant atmosphere and the absence of pressure or intimidation both psychically and physically while following the lessons in school. In the condition of schools in remote areas, there is still a gap between learning based on the needs of students with learning based on the achievement of teacher targets. This can be observed from the method of learning delivered by the teacher, where the learning method based on the needs of students, the lesson plan made by the teacher will pay attention to the average ability of students to receive learning materials, so that teachers will determine the average value minimal mastery of students with objective; while the learning method based on the achievement of the target teacher then the lesson plan made by the teacher will be guided on the performance of teachers to be achieved on each subject taught, so that the average grade of minimum mastery of students will be made based on how much the target teachers who can be accepted by students .

Such conditions as proposed by Willis (2011), Balyer (2012) that the development of human resources in the field of education is based on the ability of teachers to establish himself as a teacher and educator. Similarly Trumbull, et al (2003); Willis (2006) argues that schooling is no longer a solid building that limits children during classes, but is the second home for every child to receive knowledge, and learn to grow into a mature human being.

With regard to local wisdom, in general people in remote areas strongly adhere to local culture and habits that have been attached long before the formal education entered in the area. To this Robertson, et al (2007); Agrawal (2013) suggests Socialization of education values based on the establishment and support of cooperative working relationships between community members, government, and education department representatives. Further Shockley (2008); Severson \& DeStefano (2014) argues that local wisdom in learning in schools is applied in order to better understand the culture and customs in the area, and teachers can use learning media using basic materials in the school environment and using pasttisipasi community around Schools in the context of making teaching materials relevant to the needs of students and schools.

With regard to this matter, the meaning of local wisdom can also be approached by the synergistic relationship between the community, school and family in order to design the needs of schools and the needs of learning in schools based on the needs of schools and the needs of teachers in order to provide understanding of learning to students at school. In this case, it is necessary maturity and openness of thought to plan a learning in school with a fun atmosphere for the growth of affective, psychomotor, and cognitive aspects of students. School planning or annual program is also not free from the open attitude and adult attitudes of the existing school residents.

Thus, a child-friendly school with local wisdom will address several issues such as: (1) character-based curriculum management, as this will lead the child to good moral wisdom development and moral knowing; (2) an organizational culture in schools that promotes good practice from the local community, as this will increase meaningful education value for both the child and the school community in general; (3) the synchronization between teacher-conveyed learning and the moral message implicitly contained in the lesson plan, as this will lead to a child's understanding of self-harmony, harmony to the natural surroundings, and harmony among human beings.

\section{Clossing and Recommendation}

In general, the lessons learned that can be informed are as follows: (1) the community is increasingly growing awareness and concern for education for children which previously unknown about it; (2) the enrollment rate of children to school is higher whereas previous parents are not too concerned with the education for children because they assume that children go to school will only cost the parents; (3) children are happy to learn in the school because of educational games that have never been known and felt by them; and (4) teachers who teach at the ECE may act as a substitute parent during childhood at school.

Child friendly school can be performed well if: (1) prioritizing on process aspect rather than merely aspect of output; (2) the existence of harmony between the needs of the community with the vision, mission, and objectives of the school; (3) the existence of government policies that can be overshadowed both from aspects of mentoring and budgeting; (4) the growing awareness and mutual awareness to improve the quality of education in the regions; (5) the nature of openness of education stakeholders; and (6) delegated and programmed 
delegation of authority so that each member or community understands their duties and responsibilities.

Joyful learning which is part of the implementation of child friendly school needs to pay attention to: (1) teacher's skill in making learning innovation; (2) teachers' understanding of local culture and customs in the area; (3) the depth of teachers in making lesson plans that prioritize processes rather than outcomes; (4) the inclusion of character values to be achieved in each lesson; (5) teacher awareness to give students opportunities to be creative; (6) an appreciation for students on their learning outcomes with any conditions that can be produced by students; (7) good and regular supervision from the school principal to teachers, and from school supervisors to the schools they are co-managing; (8) a good relationship between schools with parents, community and village institutions in order to improve the quality of education in schools and villages.

Community awareness works well in order to support child-friendly schools when considering the following: (1) the existence of understanding, awareness and awareness of the importance of education for children and the advancement of education in their regions; (2) the existence of a measurable and targeted work program and good assistance from the government or NGO; (3) the existence of best practice or lesson learned from the previous project which can be used as the trigger of the spirit of the community; and (4) placing local wisdom as a local cultural richness that will enrich in the particularities of school learning in order to self-harmony, harmony of the environment, and the harmony with others.

\section{References}

Agrawal, T. (2013). Educational inequality in rural and urban India. International Journal of Educational Development, (34), 11-19.

Allen, J. (1994). Basic Education for All. The Afghan Experience. Conceptual Framework and Strategies. Paris: UNESCO

Balyer, A. (2012). Transformational Leadership Behaviors of School Principals: A Qualitative Research Based on Teachers' Perceptions. International Online Journal of Educational Sciences, 4(3), 581-591.

Creamer, D. G. (2000). Use of Theory in Academic Advising. In V. N. Gordon \& W. R. Habley (Eds.), Academic Advising: A Comprehensive Handbook. San Fransisco: Jossey-Bass, Inc.

Creamer, D. G., \& Creamer, E. G. (1994). Practicing Development Advising: Theoritical Context and Functional Application. NACADA Journal, 2(14), 17-24. https://doi.org/10.12930/0271-9517-14.2.17

Creswell, J. W. (2009). Research design: Qualitative, quantitative and mixed methods approaches (3rd ed.). Thousand Oaks, California: Sage.

Creswell, J. W. (2013). Research design: Qualitative, quantitative, and mixed method approaches. Los Angeles, California: Sage.

DuFour, R. (2004). What is a Professional Learning Community?. Educational Leadership, 61(8), 6-11.

Fitzgerald, G. (2006). Computer-Based Qualitative Data Methods. In H. A. Becker, \& F. Vanclay (Eds.), The international handbook of social impact assessment: conceptual and methodological advances. UK and USA: Edward Elgar.

Fullan, M. (2007). New Meaning of Educational Change. New York: Teachers College Press.

Hermino, A. (2015). Promoting Diversification of National Education Curriculum. Paper presented at the Symposium on National Curriculum, Hotel Mercure Ancol, Jakarta, 7 to 9 December 2015, the Ministry of Education and Culture, Republic of Indonesia (Unpublished).

Hermino, A. (2017). School-Based Management in the Rural Area, Remote Area, and Border Area of Indonesia. Bandung: AlfaBeta.

Johnson, B., \& Christensen, L. (2008). Educational research: Quantitative, qualitative, and mixed approaches. Thousand Oaks, California: Sage.

Lane, K. L., Oakes, W. P., \& Menzies, H. M. (2014). Comprehensive, Integrated, Three-Tiered Models of Prevention: Why Does My School-and District-Need an Integrated Approach to Meet Students' Academic, Behavioral, and Social Needs? International Online Journal of Routlaedge: Taylor and Francis Group. Preventing School Failure: Alternative Education for Children and Youth, 58(3), 121-128, http://dx.doi.org/10.1080/1045988X.2014.893977.

Mikkelsen, B. (2005). Methods for development work and research: A new guide for practitioners. Thousand Oaks, California New Delhi: Sage. 
Misco, T. (2007). Using Curriculum Deliberation to Address Controversial Issues: Developing Holocaust Education Curriculum for Latvian Schools. International Journal of Education Policy and Leadership, 2(8). http://www.ijepl.org

Munro \& Howe. (2013). Strengthening Local Governance and Participation for the Realisation of Children's Right to Education, January 2010 to June 2013. Final Evaluation. Vientiane: Plan International

Myers, D., \& Stonehill, R. (1993). School Based Management. Office of Research Education: Consumer Guide.

Pearce, L. (2011). Social and Cultural Barriers to Rural Adolescent Ethnic Community Girls Accessing Lower Secondary Schools in Northern Lao PDR. Vientiane: Plan International Laos and ChildFund Laos.

Peng, W.J., McNess, E., Thomas, S., Wu, X.R., Zhang, C., Li, J. Z., \& Tian, H. S. (2013). Emerging Perceptions of Teacher Quality and Teacher Development in China. International Journal of Educational Development, (34), 58-66.

Robertson, S., Novelli, M., Dale, R., Tikly, L., Dachi, H., Alphonse, N. (2007). Globalisation, Education, and Development: Ideas, Actors, and Dynamics. London: DFID.

Seel, A., I'Anson, N., \& Lomathmanyvong, S. (2015). Village Education Development Committees in Lao PDR: Their Functionallity and Impac. Vientiane: Plan International.

Severson, E. D., \& DeStefano, J. B. (2014). Leadership for Transformational Learning: A Developmental Approach to Supporting Leaders' Thinking and Practice. Journal of Research on Leadership Education, 9, 113-141. https://doi.org/10.1177/1942775114527082

Shockley, K. G. (2008). Africentric Education Leadership: Theory and Practice. International Journal of Education Policy and Leadership, 3(3).

Skaalvik, E. M., \& Skaalvik, S. (2013). Teachers' Perceptions of the School Goal Structure: Relations with Teachers' Goal Orientations, Work Engagement, and Job Satisfaction. International Journal of Educational Development, (62), 199-209. https://doi.org/10.1016/j.jier.2013.09.004

Slameto. (2010). Learning and Factors Affecting. Jakarta: Rineka Cipta

Steer, L., \& Wathne, C. (2010). Donor financing of basic education: Opportunities and constraints. International Journal of Educational Development, 30(5), 472-480. https://doi.org/10.1016/j.ijedudev.2010.03.013

Trumbull, E., Rothstein-Fisch, C., \& Hernandez, E. (2003). Parent involvement in schooling: According to whose values? The School Community Journal, 13(2), 45-72.

UNICEF. (2010). Country Annual Report for Laos, 2010: Basic Education and Gender Equality. Unpublished Report.

UNESCO. (2015). National EFA 2015 review report: Country report of Lao PDR. Vientiane: UNESCO.

Viengdavong, L., Huda, M., Supriyanto, A., \& Wiyoni, B. B. (2017). Policy Implementation of Improving Education Quality of Primary Education Teacher in Laos and Indonesia. Asian Social Science, 13(3), 145-155. https://doi.org/10.5539/ass.v13n3p145

Willis, K. (2011). Theories and Practices of Development. Abingdon, Oxon; New York: Routledge.

Willis, M. (2006). Partnership Action Learning. In Action Learning, Leadership and Organizational Development in Public Services. Edited by C. Rigg, and S. Richards. Abingdon: Routledge.

Wiles, R., Crow, G., Heath, S., \& Charles, V. (2008). The management of confidentiality and anonymity in social research. International Journal of Social Research Methodology, 11(5), 417-428. https://doi.org/10.1080/13645570701622231

\section{Copyrights}

Copyright for this article is retained by the author(s), with first publication rights granted to the journal.

This is an open-access article distributed under the terms and conditions of the Creative Commons Attribution license (http://creativecommons.org/licenses/by/4.0/). 